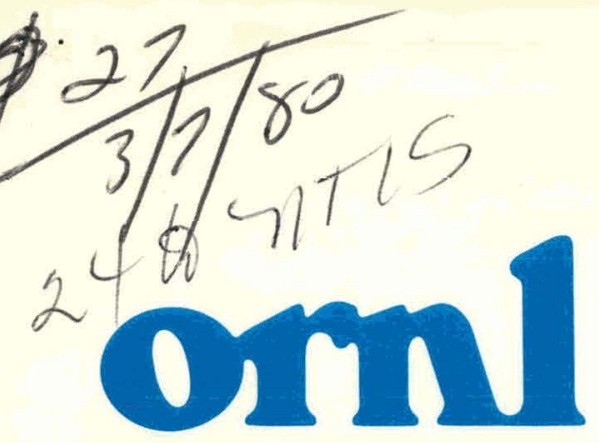

OAK

RIDGE NATIONAL LABORATORY

UNION

CARBIDE
ORNL/TM-7137

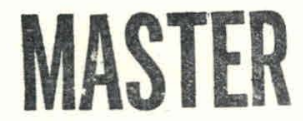

\section{Fourth Personnel Dosimetry Intercomparison Study}

\author{
H. W. Dickson
}

OPERATED BY

UNION CARBIDE CORPORATION FOR THE UNITED STATES DEPARTMENT OF ENERGY

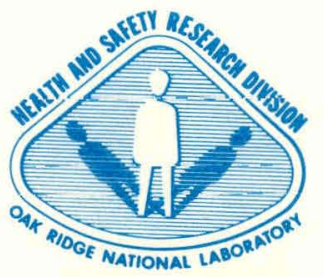




\section{DISCLAIMER}

This report was prepared as an account of work sponsored by an agency of the United States Government. Neither the United States Government nor any agency Thereof, nor any of their employees, makes any warranty, express or implied, or assumes any legal liability or responsibility for the accuracy, completeness, or usefulness of any information, apparatus, product, or process disclosed, or represents that its use would not infringe privately owned rights. Reference herein to any specific commercial product, process, or service by trade name, trademark, manufacturer, or otherwise does not necessarily constitute or imply its endorsement, recommendation, or favoring by the United States Government or any agency thereof. The views and opinions of authors expressed herein do not necessarily state or reflect those of the United States Government or any agency thereof. 


\section{DISCLAIMER}

Portions of this document may be illegible in electronic image products. Images are produced from the best available original document. 


\section{Printed in the United States of America. Available from National Technical Information Service \\ U.S. Department of Commerce \\ 5285 Port Royal Road, Springfield, Virginia 22161 \\ NTIS price codes-Printed Copy: A03 Microfiche A01}

This report was prepared as an account of work sponsored by an agency of the United States Government. Neither the United States Government nor any agency thereof, nor any of their employees, makes any warranty, express or implied, or assumes any legal liability or responsibility for the accuracy, completeness, or usefulness of any information, apparatus, product, or process disclosed, or represents that its use would not infringe privately owned rights. Reference herein to any specific commercial product, process, or service by trade name, trademark, manufacturer, or otherwise, does not necessarily constitute or imply its endorsement, recommendation, or favoring by the United States Government or any agency thereof. The views and opinions of authors expressed herein do not necessarily state or reflect those of the United States Government or any agency thereof. 
ORNL/TM-7137

Contract No. W-7405-eng-26

Health and Safety Research Division

FOURTH PERSONNEL DOSIMETRY INTERCOMPARISON STUDY

H. W: Dickson

Date Published: February 1980

NOTice This document contains information of a preliminary nature. It is subject to revision or correction and therefore does not represent a final report.

\author{
OAK RIDGE NATIONAL LABORATORY \\ Oak Ridge, Tennessee \\ operated by \\ UNION CARBIDE CORPORATION \\ for the \\ DEPARTMENT OF ENERGY
}

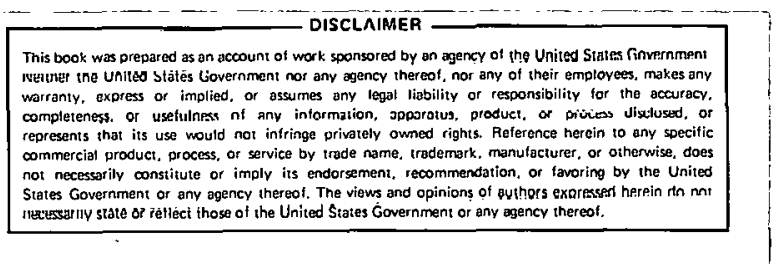


THIS PAGE

\section{WAS INTENTIONALLY LEFT BLANK}


TABLE OF CONTENTS

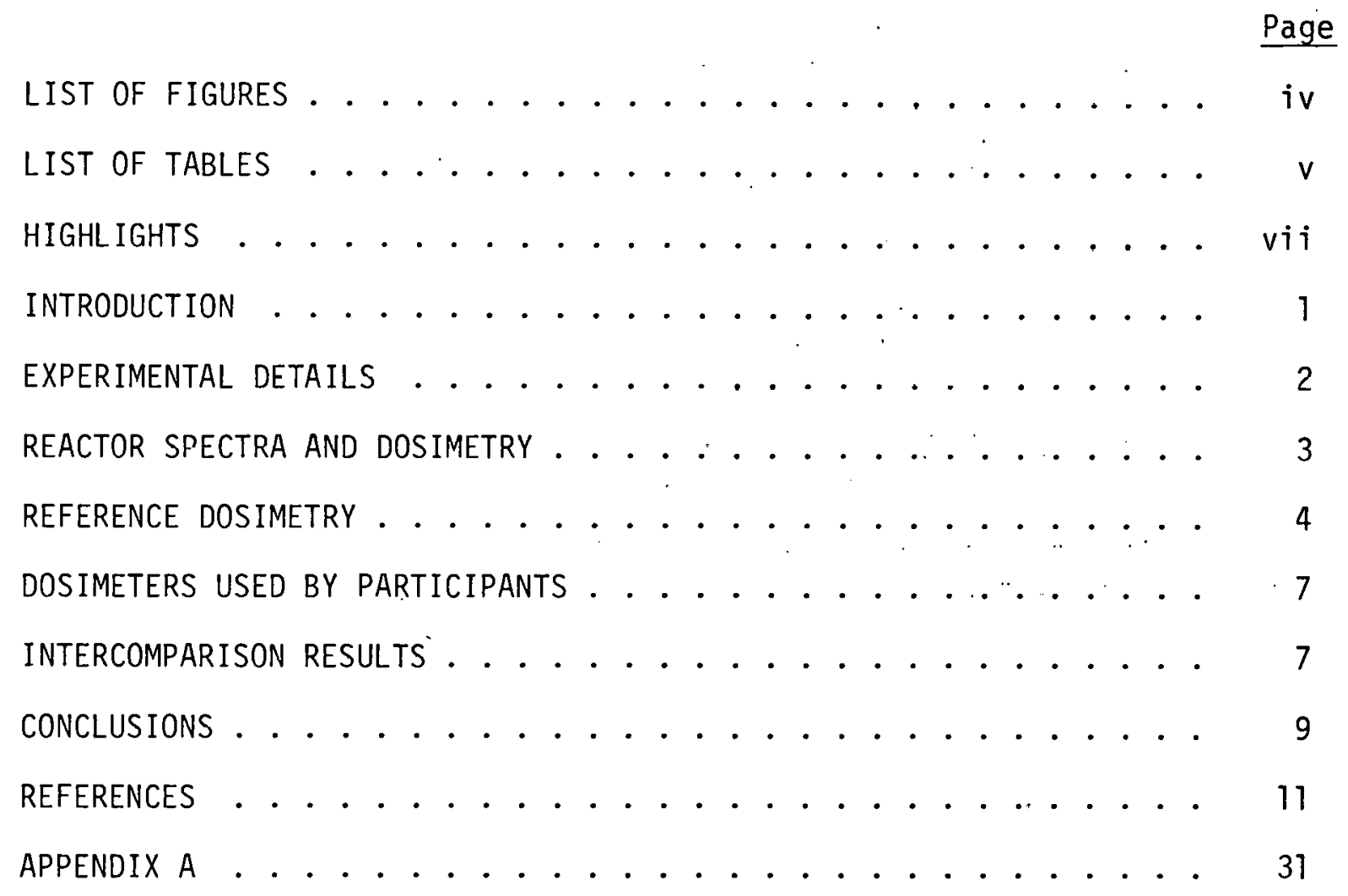


Page

$1 \quad$ Placement of dosimeters on the phantoms ........ 25

2 Typical experimental arrangement with the steel/concrete shield in place................ . . . 26

3 Calculated HPRR leakage spectrum at $3.0 \mathrm{~m}$ from the centerline of the core ............

4 Calculated neutron dose as a function of distance from the reactor centerline . . . . . . . . . 28

5 Calculated HPRR leakaye speclium at $3.0 \mathrm{~m}$ from the centerline of the reactor . . . . . . . . . .

6. Calculated neutron dose as a function of distance from

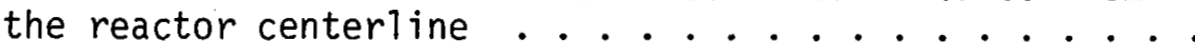


1 Summary of reactor operations for the fourth PDIS . . . . 13

2 Sulfur pellet dosimetry ................ . . 13

3 Reference dosimetry for the fourth PDIS (March 15-16, 1978) . 14

4 Reference dosimetry for the fourth PDIS (March 23, 1978) . . 14

5 Calculated doses and dose equivalents for the PDIS

operations based on reactor operating information . . . . . 15

6 Types of dosimeters used in the fourth PDIS . . . . . . 15

7 Results of participant's measurements for the unshielded HPRR exposures .................... 16

8 Results of participant's measurements for Lucite shielded HPRR exposures ................... 17

9 Results of participant's measurements for concrete-shielded HPRR exposures ................... 18

10. Results of participant's measurements for steel/concreteshielded HPRR exposures ............... . 19

11 Summary of unshielded measurements . . . . . . . . . . 20

12 Summary of Lucite-shielded measurements . . . . . . . . . 21

13 Summary of concrete-shielded measurements . . . . . . . . 22

14 Summary of steel/concrete shielded measurements . . . . : . . 23

15. Comparison of neutron measurements of the fourth PDIS with reference dosimetry ............. . . 24

16 Comparison of gamma measurements of the fourth PDIS with reference dosimetry . . . . . . . . . . . . . 24 


\section{THIS PAGE}

\section{WAS INTENTIONALLY LEFT BLANK}




\title{
FOURTH PERSONNEL DOSIMETRY INTERCOMPARISON STUDY
}

\author{
H. W. Dickson
}

HIGHLIGHTS

The fourth Personnel Dosimetry Intercomparison Study was held at the Oak Ridge National Laboratory's Dosimetry Applications Research Facility during March 15-23, 1978. The Health Physics Research Reactor (HPRR) used unshielded, with a 12-cm-thick Lucite shield, a $20-\mathrm{cm}$-thick concrete shield, or a 5-cm-thick steel and 15-cm-thick concrete shield, provided four neutron and gamma-ray spectra. The characteristics of these fields such as neutron energy spectra, intensity, and uniformity have been measured previously during nuclear accident dosimetry studies. Exposures were made to simulate total exposures likely to be encountered in personnel dosimetry. Neutron dose equivalents of the order of 500 millirems were produced by controlling the reactor power level and exposure time. Dosimeters were mounted on the trunk section of water-filled phantoms, the front edges of which were located $3 \mathrm{~m}$ from the reactor center. When shields were used, they were placed at $2 \mathrm{~m}$ from the core in the case of the Lucite shield and $1 \mathrm{~m}$ for the concrete and steel/concrete shields. Sulfur pellets exposed at a standard location on the reactor, proportional counters, and thermoluminescent dosimeters were used to perform reference dosimetry. Using the fission yield and the calculated leakage of the HPRR, the neutron fluence at the 3-m position was calculated for each reactor run. Then the dose was calculated based on the HPRR neutron spectra and dose conversion factors which had been determined previously for the four spectra. The results of these personnel dosimetry intercomparison studies reveal that estimates of dose equivalent vary over a wide range. The standard deviation of the mean of participants 
data for gamma measurements was in the range of 29 to $43 \%$; and for neutrons, it was in the range of 57 to $188 \%$.

\section{INTRODUCTION}

For the past fourteen years the annual dosimetry intercomparisons at the Oak Ridge National Laboratory's (ORNL) Dosimetry Applications Research Facility (DOSAR) have provided an opportunity for laboratories in the United States and foreign countries to test dosimetry systems in simulated nuclear accident situations. These studies have been successful in developing guidelines in instrumentation and procedures and in establishing "standardized" radiation fields whose characteristics such as energy spectrum, intensity, and uniformity have been measured and accepted. The Health Physics Research Reactor (HPRR) has been used as the pulse radiation source. The unshielded reactor or the reactor used with one of four shields provides five different neutron and gamma-ray spectra. These shields are:

1. 12-cm-thick Lucite shield,

2. 20-cm-thick concrete shield,

3. combination $5-\mathrm{cm}$-thick stee 1 and 15-cm-thick concrete shield, and

4. 13-cm-thick steel shield.

For the study described in this report only the first three shields were used. Many experimenters over the years expressed interest in using the same "standardized" radiation fields for the comparison of the response of routine personnel dosimeters used at low radiation levels typically encountered in personnel monitoring. As a result, the first Personnel Dosimetry Intercomparison Study (PDIS) was conducted during the period May 14-16, 
1974, with ten groups participating exclusive of the DOSAR group. Three additional intercomparison studies for personnel dosimeters have been completed at ORNL. The second PDIS was conducted February 18-19, 1976, with eleven participating groups; the third PDIS was held March 15-16, 1977, with seven participating groups; and the fourth PDIS was conducted March 15-23, 1978, with twenty-two participating groups (Appendix A contains a list of participants).

\section{EXPERIMENTAL DETAILS}

The HPRR was used as the source of gamma and neutron fields. The radiation properties of several of the possible fields around the HPRR have been measured ${ }^{1-3}$ and calculated ${ }^{1,5}$ in previous studies. The HPRR is a small, unshielded and unmoderated, fast reactor suitable for research in health physics, radiobiology, biomedicine, and related fields. The reactor core is a right circular cylinder $(0.23-\mathrm{m}$ diam, $0.20-\mathrm{m}$ high) of enriched uranium (93.14 wt \% ${ }^{235} U$ ) alloyed with $10 \%$ molybdenum. Its fuel plates are coated with nickel and held together by fuel bolts. It has one large scrammable fuel element (the safety block) and three rnntrol rods, one of which can be inserted rapidly to produce a pulse of radiation. A more complete description of the HPRR is provided by Auxier. 6

The HPRR was used to expose personnel dosimeters to mixed neutron and gamma fields. The reactor was operated as shown in Table 1 in a steady-state mode at a constant power level for a length of time necessary to produce dose equivalents of a few hundred millirems which is the range likely to be encountered in personnel monitoring. In order to produce this range of radiation levels, a free air tissue kerma of 
approximately 50 millirads was required for the neutron component; and the reactor operating time was calculated based on this kerma. Generally, the dosimeters were mailed or shipped to the DOSAR a few days in advance of the intercomparison. The dosimeters were then returned in a similar manner the day after the intercomparison exposures were completed.

Al1 dosimeters were placed on water-filled trunk portions of phantoms, the leading edges of which were located $3 \mathrm{~m}$ from the reactor core. When shields were used, they were placed between the detectors and the HPRR core, at a distance of $2 \mathrm{~m}$ for the Lucite shield and at a distance of $1 \mathrm{~m}$ for the concrete and steel/concrete shields. The placement of dosimeters on the phantoms is shown in Fig. 1, and a typical experimental arrangement with reactor and shield in place is shown in Fig. 2. Several phantoms, water bottles, and other containers were used as labeled in Fig. 2 to accommodate all of the dosimeters and special requests by participants.

During the fourth PDIS, several sets of dosimeters arrived late and had to be exposed in separate but equivalent reactor operations. Dosimeters for sixteen groups were exposed March 15-16, 1978, and dosimeters from five groups were exposed March 23, 1978. The same reference dosimetry was performed for each set of dosimeters. All of the reactor parameters listed in Table 1 apply to both periods of irradiation. The runs designated 1 through 4 applied to the March 15-16 time frame and the runs designated 5 through 8 applied to the March 23 date.

\section{REACTOR SPECTRA AND DOSIMETRY}

Calculations of the HPRR spectra have been performed using a twodimensional discrete ordinates transport (DOT) code which assumed cylindrical symmetry about the vertical axis of the HPRR core. The 
first set of calculations ${ }^{4}$ was done for the unshielded reactor and the reactor with the Lucite and steel shields in place (see Fig. 3). These calculations were performed using 34 energy groups of neutrons ranging from thermal to $14 \mathrm{MeV}$. The reactor height was fixed at $150 \mathrm{~cm}$ above a 30-cm-thick concrete slab. The shielding configurations were a $13-\mathrm{cm}-$ thick steel shield rising $213 \mathrm{~cm}$ above the concrete slab and a 12-cmthick Lucite shield rising $282 \mathrm{~cm}$ above the slab. The fronts of these shields were placed at $200 \mathrm{~cm}$ from the reactor center. In addition to neutron spectra, these calculations also provided neutron dose as a function of distance from the reactor (shown in Fig. 4).

Recently, other calculations ${ }^{5}$ have been performed to determine the neutron spectra (see.Fig. 5) and dose (see Fig. 6) through two new shield configurations - a $20-\mathrm{cm}$-thick concrete shield and a combination 5-cm-thick steel and 15-cm-thick concrete shield. Each of these shields is $213 \mathrm{~cm}$ in height. Ihese calculations were done using the previous calculational model except that the shields were located $100 \mathrm{~cm}$ from the center of the reactor and only 33 energy groups were used.

\section{REFERENCE DOSIMETRY}

In addition to the calculated neutron dose, various dosimetric devices were applied to obtain the true neutron dose delivered during the intercomparison. These devices included the routine sulfur pellet monitors on the reactor and Hurst proportional counters located at the position of the exposed dosimeters (see Fig. 2). While sulfur pellets respond only to the neutron fluence above a threshold of approximately $2.5 \mathrm{MeV}$, they may be used to monitor the reactor output since a large 
percentage of neutrons from the HPRR $(\sim 30 \%)$ exceed this energy. Also, because a constant fraction of the neutrons for any given shielded configuration will have an energy above the sulfur threshold, the sulfur pellets can be used to estimate neutron tissue kerma for all the experimental conditions once the calibration factor has been determined for each of the spectra. These calibration factors have been determined previously from nuclear accident dosimetry intercomparison experience ${ }^{7-9}$ at the HPRR. Therefore, the sulfur pellets exposed at a standard location on the reactor during the intercomparisons served as a basis for estimates of tissue kerma at the experimental position. The results of the sulfur pellet dosimetry are given in Table 2.

In the case of the unshielded reactor and the Lucite-shielded reactor, average quality factors for the neutron spectra are available in the literature; 10 and these values were used as the best available data. Independent calculations by the author, performed in the manner indicated below, support the literature values. Literature values were not available for the concrete or steel/concrete shields.

For the concrete- and steel/concrete-shielded cases, the quality factoris were calculated based on data from ref. 11. Using the previously calculated spectra ${ }^{5}$ through the concrete and steel/concrete shields, it was possible to calculate spectrally weighted dose and dose equivalent conversion factors. This was accomplished by taking the product of a dose (or dose equivalent) conversion factor from ref. 11 and the fraction of the neutron fluence in a given energy interval, and then summing over the 33 energy intervals in the complete spectrum. Finally, the spectrally weighted dose equivalent conversion factor was divided by the spectrally 
weighted dose conversion factor to give the quality factors for the concrete and steel/concrete spectra. These calculated quality factors are given in Table 2 along with an estimated error of 5\%. The error estimate is based on the fact that the use of other generally accepted dose and dose equivalent conversion factors ${ }^{12,13}$ lead to slightly different quality factors.

A Hurst proportional counter ${ }^{14}$ was used to measure the absorbed dose from neutrons. The absorbed dose is proportional to the size and number of pulses from this counter; therefore, the pulse height distribution was obtained with a multichannel analyzer and read into a PDP-10 computer for analysis. The pulse height distribution from the Hurst counter was due largely to neutron interactions; however, gamma radiation contributed to the low energy end of the spectrum. In order to determine only the neutron response, the computer program incorporated a stripping routine to remove the gamma response. The counter was calibrated using an Am-Be neutron source that had been standardi<ed by the Nationa? Bureau of Standards in terms of neutron yield. The results of these measurements are given in Tables 3 and 4.

Gamma radiation levels were measured with thermoluminescent dosimeters (TLD's). Lithium fluoride dosimeters having normal isotopic component.s (TLD-100) and dosimeters having an enrichment of ${ }^{7}$ Li (TLD-700) were used in pairs to obtain the yamina-ray exposure in the prisence of neutrons. The differential neutrons response of these dosimeters had heen determined previously. The TLD's were calibrated for gamma exposure using a ${ }^{226} \mathrm{Ra}$ source. The results of these measurements also are given in Tables 3 and 4 . The error in these measurements is estimated not to exceed 
In addition, the neutron dose equivalent for the intercomparison exposures were calculated. Using dose conversion factors for that section of a phantom ${ }^{12}$ designated as element 57 , the dose conversion factors for the HPRR spectra were calculated. Using the fission yield as determined by reactor instrumentation and the calculated leakage ${ }^{15}$ of the HPRR, the neutron fluence was calculated for each reactor run. By applying the previously determined dose conversion factors and average quality factors (given in Table 2), the dose and dose equivalent were calculated for each experimental configuration (see Table 5). The results for the concrete and steel/concrete shields were anomalously high suggesting problems with the calculations of these spectra from the DOT code.

\section{DOSIMETERS USED BY PARTICIPANTS}

Several types of dosimeters were used by the participants in this PDIS. For measuring the neutron component, TLD albedo and nuclear track film, type A (NTA) film dosimeters were the most numerous; however, track-etch dosimeters using polycarbonate films are gaining in popularity. For measuring the gamma components, onty film and TLD's were used, with TLD's being used most frequently. A breakdown of dosimeter types by participating group is given in Table 6.

\section{INTERCOMPARISON RESULTS}

The results of these personnel dosimetry intercomparison studies reveal that estimates of dose equivalent vary over a wide range. The results of all the reported measurements are given in Tables 7-10. While it was preferable to report every individual measurement, a few participants averaged measurements and reported only the average values. 
Most of the dosimeters were exposed on phantoms A, B, or C (all identical for the purposes of this intercomparison); however, a few measurements were either made in air or on a water bottle by special request of the participant. The phantoms, water bottles, and air stations are marked in Fig. 2. These exceptions are pointed out in Tables 7-10. One participant used TLD-100 for gamma measurements without anticipating the effect of neutrons. The result was that the data could not be corrected for neutron response and is included in Tables 7-10 only for the sake of completeness. The data was not used for the summaries that follow.

Because similar operations were performed on two separate occassions to include all dosimeters, some effort has been made to identify measurements with the date on which they were made. One set of reactor runs was conducted March 15-16 and another set on March 23. The reactor was operated for the same length of time and at the same power level in both sets of runs. Consequently, one would not expect differences in the neutron dose between these sets of runs, and real differences were not observed. The gamina doses are a function not only of the reactur operation but how long the dosimeters stayed in the high background area around the reactor. Since this "stay" time could have varied between sets of operations, it was more important to keep track of potential differences in gamma dose. A real difference in gamma doses was observed only for the two different unshielded reactor exposures.

The participant data are summarized in Tables 11-14 for the different exposure conditions. No minimal or zero values were used in these summaries. The results would have looked worse häd these values been used. 
Since the median is a central tendency parameter which tends to minimize the impact of extreme data points, it was chosen as one statistic to be presented. This minimized the inclination to "sort the data" by throwing out obvious outliers. Consequently, the means and standard deviations in Tables 11-14 reflect nearly all the data (exceptions already mentioned).

For intercomparison studies, it is important to see how well the participants' measurements agree with reference values of radiation dose equivalent as well as with each others' experimental results. The neutron dose equivalents as determined for the two sets of runs (see Tables 2-4) were averaged for both the proportional counter and the sulfur pellets, independently, to serve as the reference values. These values are compared with the mean and median values of the participant's measurements in Table 15. Reference dosimetry as determined by sulfur pellets has a larger uncertainty than doses determined by the Hurst proportional counter. This is especially true for the concrete and steel/concrete shields for which the attenuation factors are not well known. A comparison of gamma reference dosimetry with participant's results is given in Table 16 . While the data have been kept separate for the two sets of runs, it appears that only data from the unshielded part of the experiment needed to be separated.

\section{CONCLUSIONS}

A few tentative conclusions are suggested by this study; however, one needs to be cautious since some data points represent only a few measurements. Perhaps the data from all the PDIS studies could be combined to yield more definitive conclusions. It appears that NTA film 
(see Tables $11-14$ ) consistently underestimates the dose. This would be even more dramatically portrayed if zero and minimal values had been included: Other neutron dosimeter types respond about equally well (if one considers $\pm 50-100 \%$ acceptable).

Film has a smaller standard deviation than TLD's for gamma dosimetry. This observation is based on too little data to be conclusive, however. Overall, standard deviations were excessively large. Few of the dosimeters in this PDIS would pass the guidelines contained in a draft American National Standard ${ }^{16}$ and supported by the Nuclear Regulatory Commission. The few bright spots were for dosimeter types mirimally represented and consequently lack the degree of confidence that is required to allow one to assert acceptable performance. For example, track-etch dosimeters generally agreed with the reference dosimetry and had a smaller standard deviation than albedo dosimeters.

This type of intercomparison activity was found to be valuable to the participants, and the results are indicative of some lrouble spots in the interpretation of dosimeter responses. The participants and dosimeters have not been the same from one year's study to the next, and there is no reason to believe that the same participants will continue year after year. Thus, new groups can be helped by offering this activity on a continuing basis. It is anticipated that this type of intercomparison study will be worthwhile on an annual basis unt1l the - problems in dosimeter response and interpretation have been identified and solved. 


\section{REFERENCES}

1. H. W. Dickson, W. F. Fox, and F. F. Haywood, 1974 Intercomparison of Personnel Dosimeters, ORNL/TM-4786 (January 1976).

2. L. W. Gilley, H. W. Dickson, and D. J. Christian, 1976 Intercomparison of Personnel Dosimeters, ORNL/TM-5672 (December 1976).

3. L. W. Gilley and H. W. Dickson, Third Personnel Dosimetry Intercomparison Study, ORNL/TM-6114 (January 1979).

4. J. W. Poston, J. R. Knight, and G. E. Whitesides, "Calculation of the HPRR neutron spectrum for simulated nuclear accident conditions," Health Phys. 26, 217 (1974).

5. H. W. Dickson and L. W. Gilley, "Personnel Dosimetry Intercomparison Studies at the ORNL Health Physics Research Reactor," Symposium on National and International Standardization in Radiation Dosimetry, December 5-9, 1977, Atzanta, Georgia, International Atomic Energy Agency (1977).

6. J. A. Auxier, "The Health Physics Research Reactor," Heazth Phys. 11, $89(1965)$.

7. H. W. Dickson, F. F. Haywood, and K. Becker, Tenth Dosimetry Intercomparison Study, ORNL/TM.4566 (March 1975).

8. C. S. Sims and H. W. Dickson, "Nuclear Accident Dosimetry Intercomparison Studies at the Health Physics Research Reactor: A Summary (1965-1978)," Health Phys. 37, 687 (1979).

9. C. S. Sims, Fưrteenth Nuclear Accident Dosimetry Intercomparison Study: July 13-22, 1977, ORNL/TM-6773 (June 1979).

10. M.S.S. Murthy, R. C. Bhatt, and S. S. Shinde, "Estimation of Quality Factor and RBE for Degraded Fission Neutron Spectra," Health phys. 27, 9 (1974). 
11. National Council on Radiation Protection and Measurement, Protection Against Neutron Radiation, NCRP Report No. 38 (1971).

12. F. H. Attix and W. C. Roesch (eds.), Radiation Dosimetry, pp. 294298, Vo1. 1, Academic Press, New York, 1968.

13. International Commission on Radiation Units and Measurements, Neutron Fluence, Neutron Spectra and Kerma, ICRU Report 13. (1969).

14. G. S. Hurst, "An Absolute Tissue Dosemeter for Fast Neutrons," Br. J. Radioz. 27, 353 (1954).

15. D. R. Johnson and J.W. Poston, Radiation Dosimetry Studies at the Health Physics Research Reactor, ORNL-4113 (1967).

16. American National Standards Institute, "Criteria for Testing Personnel Dosimeter Performance," Draft American National Standard, N13.11 (JuTy 1978). 
Table 1. Summary of reactor operations for the fourth PDIS

\begin{tabular}{llccc}
\hline Run & Shield & $\begin{array}{c}\text { Power } \\
(\text { watt })\end{array}$ & $\begin{array}{c}\text { Time } \\
(\mathrm{sec})\end{array}$ & $\begin{array}{c}\text { Fissions } \\
\left(10^{13}\right)\end{array}$ \\
\hline 1 and 5 & None & 2 & 1.87 & 1.16 \\
2 and 6 & Lucite & 2 & 990 & 6.14 \\
3 and 7 & Concrete & 1.7 & 1285 & 6.77 \\
4 and 8 & Steel/Concrete & 1.9 & 1328 & 7.83 \\
\hline
\end{tabular}

Table 2. Sulfur pellet dosimetry

\begin{tabular}{llllll}
\hline Run & Date & Shield & $\begin{array}{c}\text { Kerma } \\
\text { (millirad) }\end{array}$ & QF & $\begin{array}{c}\text { Dose } \\
\text { equivalent } \\
\text { (millirem) }\end{array}$ \\
\hline 1 & $3 / 15 / 78$ & None & $45.9 \pm 10 \%$ & $9.4 \pm 4 \%$ & $431 \pm 46$ \\
2 & $3 / 15 / 78$ & Lucite & $49.2 \pm 11 \%$ & $8.9 \pm 5 \%$ & $438 \pm 53$ \\
3 & $3 / 16 / 78$ & Concrete & $67.8 \pm 16 \%$ & $8.6 \pm 5 \%$ & $583 \pm 97$ \\
4 & $3 / 16 / 78$ & Steel/ & $71.0 \pm 19 \%$ & $8.8 \pm 5 \%$ & $625 \pm 123$ \\
& & Concrete & & & \\
5 & $3 / 23 / 78$ & None & $49.4+10 \%$ & $9.4 \pm 4 \%$ & $161 \pm 50$ \\
6 & $3 / 23 / 78$ & Lucite & $53.3 \pm 11 \%$ & $8.9 \pm 5 \%$ & $474 \pm 57$ \\
7 & $3 / 23 / 78$ & Concrete & $63.3 \pm 16 \%$ & $8.6 \pm 5 \%$ & $544 \pm 91$ \\
8 & $3 / 23 / 78$ & Steel/ & $70.0 \pm 19 \%$ & $8.8 \pm 5 \%$ & $616 \pm 121$ \\
& & Concrete & & & \\
\hline
\end{tabular}

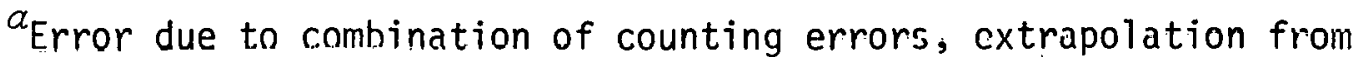
location of pellet to dosimeter position and uncertainty in shielding attenuation factors. 
Table 3. Reference dosimetry for the fourth PDIS (March 15-16, 1978)

\begin{tabular}{lcccc}
\hline $\begin{array}{l}\text { Exposure } \\
\text { condition }\end{array}$ & $\begin{array}{c}\text { Neutron dose } \\
\text { (millirad) }\end{array}$ & $\begin{array}{c}\text { Neutron } \\
\text { QF }^{a}\end{array}$ & \multicolumn{2}{c}{$\begin{array}{c}\text { Dose equivalent } \\
\text { (millirem) }\end{array}$} \\
\hline Unshielded & 51.2 & 9.4 & $481 \pm 52$ & 32 \\
Lucite & 46.8 & 8.9 & $416 \pm 47$ & 41 \\
Concrete & 51.7 & 8.6 & $445 \pm 50$ & 27 \\
Steel/Concretc & 53.1 & 8.8 & $467 \pm 52$ & 24 \\
\hline
\end{tabular}

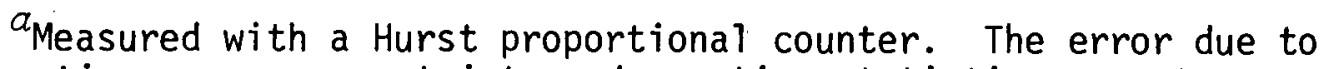
calibration source uncertainty and counting statistics amounts to approximately $10 \%$.

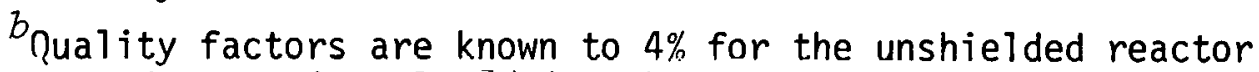
spectrum and approximately $5 \%$ for the various shielded spectra.

${ }^{c}$ Reference gamma dosimetry performed using TLD's.

Table 4. Reference dosimetry for the fourth PDIS (March 23, 1978)

\begin{tabular}{lcccc}
\hline $\begin{array}{l}\text { Expusure } \\
\text { condition }\end{array}$ & $\begin{array}{c}\text { Neutron dose } \\
\text { (millirad) }\end{array}$ & $\begin{array}{c}\text { Neutron } \\
\text { QF }^{a}\end{array}$ & \multicolumn{2}{c}{$\begin{array}{c}\text { Dose equivalent } \\
\text { (millirem) }\end{array}$} \\
\hline Unshielded & 46.0 & 9.4 & $432 \pm 47$ & 15 \\
Lucite & 52.1 & 8.9 & $466 \pm 5 ?$ & 53 \\
Concrete & 49.2 & 8.6 & $423 \pm 47$ & 33 \\
Steel/Concrete & 47.6 & 8.8 & $419 \pm 47$ & 33 \\
\hline
\end{tabular}

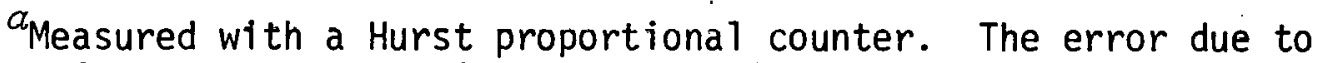
calibration source uncertainty and counting statistics amounts to approximately $10 \%$.

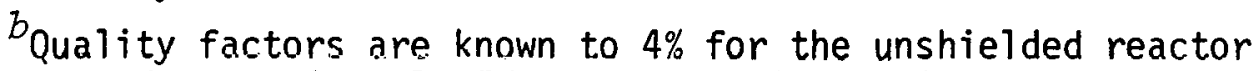
spectrum and approximately $5 \%$ for the various shielded spectra.

${ }^{c}$ Reference gamma dosimetry performed using TLD's. 
Table 5. Calculated doses and dose equivalents for PDIS operations based on reactor operating information

\begin{tabular}{lcccc}
\hline Shield & $\begin{array}{c}\text { Fissions } \\
\left(10^{13}\right)\end{array}$ & $\begin{array}{c}\text { Fluence } \\
\left(\mathrm{cm}^{-2} \times 10^{-7}\right)\end{array}$ & $\begin{array}{c}\text { Dose } \\
(\mathrm{mi} \text { li irad })\end{array}$ & $\begin{array}{c}\text { Dose equivalent } \\
(\text { millirem })\end{array}$ \\
\hline None & 1.16 & 2.34 & 59.7 & 561 \\
Lucite & 6.14 & 3.26 & 47.5 & 423 \\
Concrete & 6.77 & 6.77 & 91.8 & 789 \\
Steel/ & 7.83 & 7.60 & 92.7 & 816 \\
Concrete & & & & \\
\hline
\end{tabular}

Table 6. Types of dosimeters used in the fourth PDIS

\begin{tabular}{lll}
\hline \multicolumn{1}{c}{ Group } & $\begin{array}{c}\text { Neutron } \\
\text { dosimeter }\end{array}$ & $\begin{array}{c}\text { Gamma } \\
\text { dosimeter }\end{array}$ \\
\hline Argonne National Laboratory & NTA film & Film \\
Battelle PNL & TLD albedo & TLD \\
Cornell University & TLD \\
Czechoslovak Academy of Sciences & Track etch & \\
Department of Navy & TLD albedo & TLD \\
Department of Energy/I00 & TLD albedo & TLD \\
Eberline Instrument Corporation & TLD & TLD \\
Fermi Laboratory & NTA film/Track etch & Film/TLD \\
Goodyear Atomic Corporation & TLD albedo & TLD \\
Kernforschungszentrum Karlsruhe & TLO & \\
Lawrence Berkeley Laboratory & TLD albedo/ & TLD \\
Lawrence Livermore Laboratory & Track etch & \\
R. S. Landauer, Jr. \& Company & Track etch & TLD \\
Rockwell International & TLD albedo & TLD \\
Savannah River Plant & TLD albedo & TLD \\
Stanford University & TLD albedo & TLD \\
Teledyne Isotopes & TLD & TLD \\
Tennessee Valley Authority & Film \\
University of California, Davis & NTA film & \\
University of San Francisco & Track etch & TLD \\
Westinghouse, Bettis & TLD albedo & Film \\
Yale University & NTA film & \\
\hline
\end{tabular}


Table 7. Results of darticinant 's measurements for the unshielded IPRR exposures

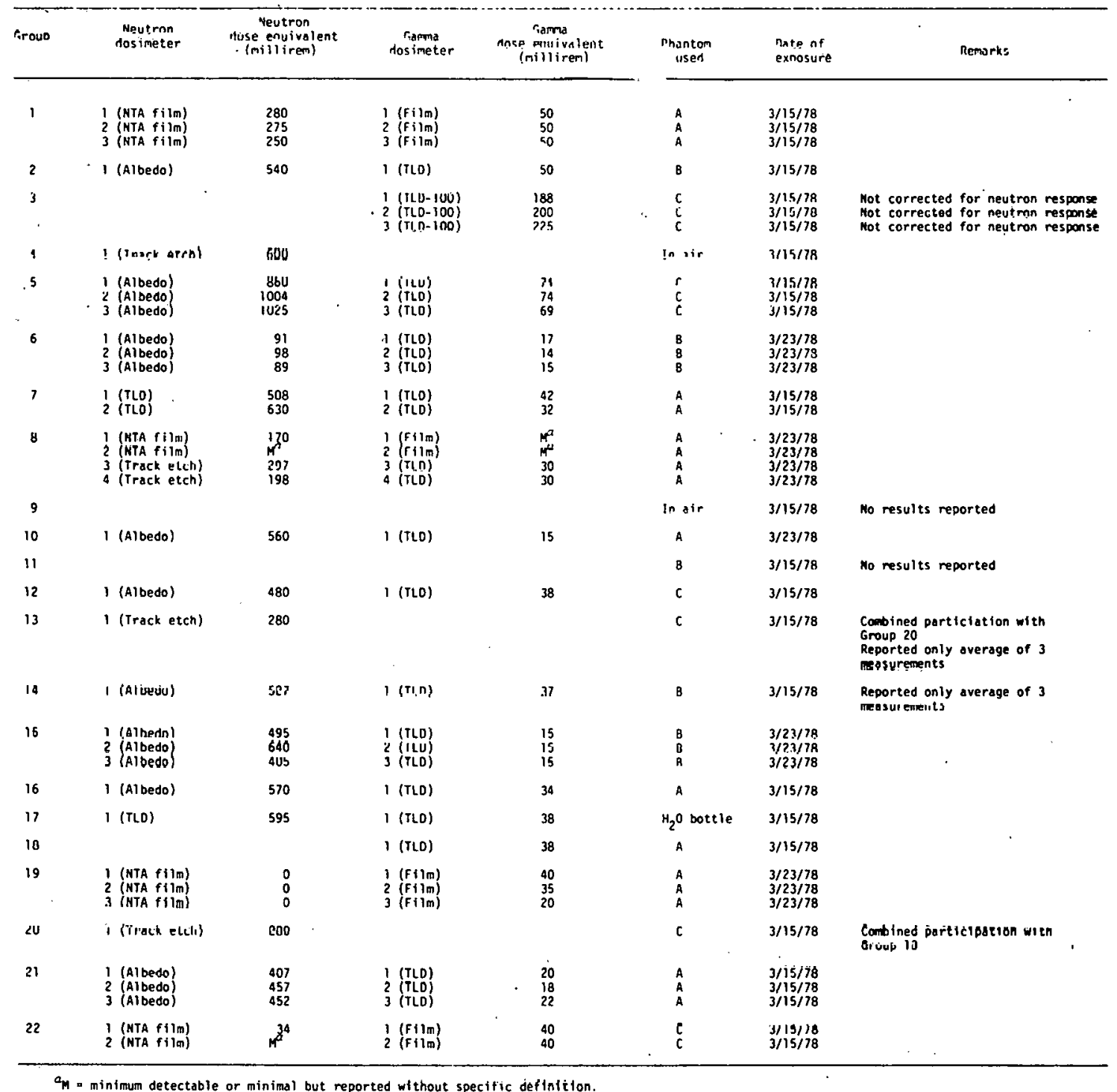


Table 8. Results of narticipant's medsurements for Lucite shielded HPRR exnosures

\begin{tabular}{|c|c|c|c|c|c|c|c|}
\hline Firoun & $\begin{array}{l}\text { Yeutron } \\
\text { dosineter }\end{array}$ & $\begin{array}{l}\text { 'Jeutron } \\
\text { hose enuivalent } \\
\text { (nillirem) }\end{array}$ & $\begin{array}{l}\text { Frama } \\
\text { cosimeter }\end{array}$ & $\begin{array}{l}\text { rarma } \\
\text { dose equivalent } \\
\text { (millirem) }\end{array}$ & $\begin{array}{c}\text { Dhantom } \\
\text { used }\end{array}$ & $\begin{array}{l}\text { Date of } \\
\text { exnosure }\end{array}$ & Remarks \\
\hline 1 & $\begin{array}{l}1 \text { (NTA film) } \\
2 \text { (NTA film) } \\
3 \text { (NTA film) }\end{array}$ & $\begin{array}{l}205 \\
225 \\
230\end{array}$ & $\begin{array}{l}1(F i l m) \\
2(F i \mid m) \\
3(F i \mid m)\end{array}$ & $\begin{array}{l}55 \\
50 \\
50\end{array}$ & $\hat{A}$ & $\begin{array}{l}3 / 15 / 78 \\
3 / 15 / 78 \\
3 / 15 / 78\end{array}$ & \\
\hline 2 & & & $1(T L D)$ & 70 & $B$ & $3 / 15 / 78$ & \\
\hline 3 & . & & $\begin{array}{l}1(\mathrm{TLO}-100) \\
2(\mathrm{TLO}-100) \\
3(\mathrm{TLO}-100)\end{array}$ & $\begin{array}{l}827 \\
805 \\
877\end{array}$ & $\begin{array}{l}c \\
c \\
c\end{array}$ & $\begin{array}{l}3 / 15 / 78 \\
3 / 15 / 78 \\
3 / 15 / 78\end{array}$ & $\begin{array}{l}\text { Not corrected for neutron response } \\
\text { Mot corrected for neutron response } \\
\text { Mot corrected for neutron response }\end{array}$ \\
\hline 4 & I (Track etch) & 690 & & & In oir & $3 / 15 / 78$ & \\
\hline 5 & $\begin{array}{l}1 \text { (Albedo) } \\
2 \text { (Albedo) } \\
3 \text { (Albedo) }\end{array}$ & $\begin{array}{l}1342 \\
1139 \\
1249\end{array}$ & $\begin{array}{l}1(T L D) \\
2(T L D) \\
3(T L D)\end{array}$ & $\begin{array}{l}118 \\
138 \\
136\end{array}$ & $\begin{array}{l}c \\
c \\
c\end{array}$ & $\begin{array}{l}3 / 15 / 78 \\
3 / 15 / 78 \\
3 / 15 / 78\end{array}$ & \\
\hline 6 & $\begin{array}{l}1 \text { (Albedo) } \\
2 \text { (Albedo) } \\
3 \text { (Albedo) }\end{array}$ & $\begin{array}{l}221 \\
193 \\
211\end{array}$ & $\begin{array}{l}1 \text { (TLD) } \\
2 \text { (TLD) } \\
3(T L D)\end{array}$ & $\begin{array}{l}67 \\
67 \\
58\end{array}$ & $\begin{array}{l}8 \\
8 \\
B\end{array}$ & $\begin{array}{l}3 / 23 / 78 \\
3 / 23 / 78 \\
3 / 23 / 78\end{array}$ & \\
\hline 7 & $\begin{array}{l}1(\mathrm{TLO}) \\
2(\mathrm{TLO}) \\
3 \text { (TLO) }\end{array}$ & $\begin{array}{l}421 \\
447 \\
447\end{array}$ & $1(T L D)$ & 0 & $\begin{array}{c}A \\
A \\
A\end{array}$ & $\begin{array}{l}3 / 15 / 78 \\
3 / 15 / 78 \\
3 / 15 / 78\end{array}$ & \\
\hline 8 & $\begin{array}{l}1 \text { (NTA film) } \\
2 \text { (NTA film) } \\
3 \text { (Track etch) } \\
4 \text { (Track etch) }\end{array}$ & $\begin{array}{l}168 \\
18 \\
240 \\
192\end{array}$ & $\begin{array}{l}1(f i \mid m) \\
2(F i \mid m) \\
3(T L O) \\
4 \text { (ILO) }\end{array}$ & $\begin{array}{r}80 \\
80 \\
130 \\
120\end{array}$ & $\begin{array}{l}A \\
A \\
A \\
A\end{array}$ & $\begin{array}{l}3 / 23 / 78 \\
3 / 23 / 78 \\
3 / 23 / 78 \\
3 / 23 / 78\end{array}$ & $\cdot$ \\
\hline 9 & & & & & In air & $3 / 15 / 78$ & No results reported \\
\hline 10 & 1 (Albedo) & 420 & $1(\mathrm{TLO})$ & 50 & . A & $3 / 23 / 78$ & \\
\hline 11 & & & & & & & $\begin{array}{l}\text { Did not participate in this } \\
\text { exposure }\end{array}$ \\
\hline 12 & $\begin{array}{l}1 \text { (Albedo) } \\
2 \text { (Track etch } \\
\text { albedo comb.) }\end{array}$ & $\begin{array}{l}510 \\
629\end{array}$ & $1\langle T L 0\rangle$ & 34 & c & $\begin{array}{l}3 / 15 / 78 \\
3 / 15 / 78\end{array}$ & \\
\hline 13 & I (Track eteh) & 460 & & & c & $3 / 15 / 78$ & $\begin{array}{l}\text { Combined participation with froup } 20 \\
\text { Reported only average of } 3 \text { messure- } \\
\text { ments }\end{array}$ \\
\hline 14 & 1 (Albedo) & 483 & $1(\mathrm{TLO})$ & 61 & 8 & $3 / 15 / 78$ & $\begin{array}{l}\text { Reported only average of } 3 \text { measure- } \\
\text { ments }\end{array}$ \\
\hline 15 & $\begin{array}{l}1 \text { (Albedo) } \\
2 \text { (Albedo) } \\
3 \text { (Albedo) }\end{array}$ & $\begin{array}{l}600 \\
625 \\
570\end{array}$ & $\begin{array}{l}1 \\
2(\mathrm{TLO}) \\
3(\mathrm{TLO}) \\
3(\mathrm{TLO})\end{array}$ & $\begin{array}{l}50 \\
60 \\
55\end{array}$ & $\begin{array}{l}8 \\
8 \\
B\end{array}$ & $\begin{array}{l}3 / 23 / 78 \\
3 / 23 / 78 \\
3 / 23 / 78\end{array}$ & \\
\hline 16 & 1 (Albedo) & 350 & $1\{\mathrm{TLO})$ & 47 & A & $3 / 15 / 78$ & \\
\hline 17 & $1(T L O)$ & 496 & $1(T L O)$ & 67 & $\mathrm{H}_{2} \mathrm{O}$ bottle & $3 / 15 / 78$ & \\
\hline 18 & & & $1(\mathrm{TLO})$ & 67 & .8 & $3 / 15 / 78$ & \\
\hline 19 & $\begin{array}{l}1 \text { (NTA film) } \\
2 \text { (NTA fYim) } \\
3 \text { (NTA fiIm) }\end{array}$ & $\begin{array}{r}15 \\
0 \\
n\end{array}$ & 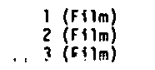 & $\begin{array}{l}80 \\
85 \\
65\end{array}$ & $\begin{array}{l}A \\
A\end{array}$ & $\begin{array}{l}3 / 23 / 78 \\
3 / 23 / 78 \\
j / 23 / 18\end{array}$ & \\
\hline 20 & I (Track etch) & 460 & . & & c. & $3 / 15 / 78$ & Combined participation $=1$ lis Gruup 20 \\
\hline 21 & $\begin{array}{l}1 \text { (Albedo) } \\
2 \text { (Albedo) } \\
3 \text { (Albedo) }\end{array}$ & $\begin{array}{l}273 \\
? 61 \\
? 74\end{array}$ & $\begin{array}{l}1(\mathrm{TLO}) \\
2(\mathrm{TLO}) \\
3(\mathrm{TLO})\end{array}$ & $\begin{array}{l}55 \\
49 \\
67\end{array}$ & $\begin{array}{l}\text { A } \\
\text { A } \\
\text { A }\end{array}$ & $\begin{array}{l}3 / 15 / 78 \\
3 / 15 / 78 \\
3 / 15 / 78\end{array}$ & \\
\hline 22 & $\begin{array}{l}1 \text { (NTA } f(1 m) \\
2 \text { (NTA film) }\end{array}$ & 189 & $\begin{array}{l}1 \\
2(\mathrm{Film})\end{array}$ & $\begin{array}{l}80 \\
80\end{array}$ & $\begin{array}{l}c \\
c\end{array}$ & $\begin{array}{l}3 / 15 / 79 \\
3 / 15 / 79\end{array}$ & \\
\hline
\end{tabular}

$a_{M}=$ minimum detectable or minimal but reported with no specific definition. 
Table 9. Results of narticioant's measurements for concrete-shielded HPRR exoosures

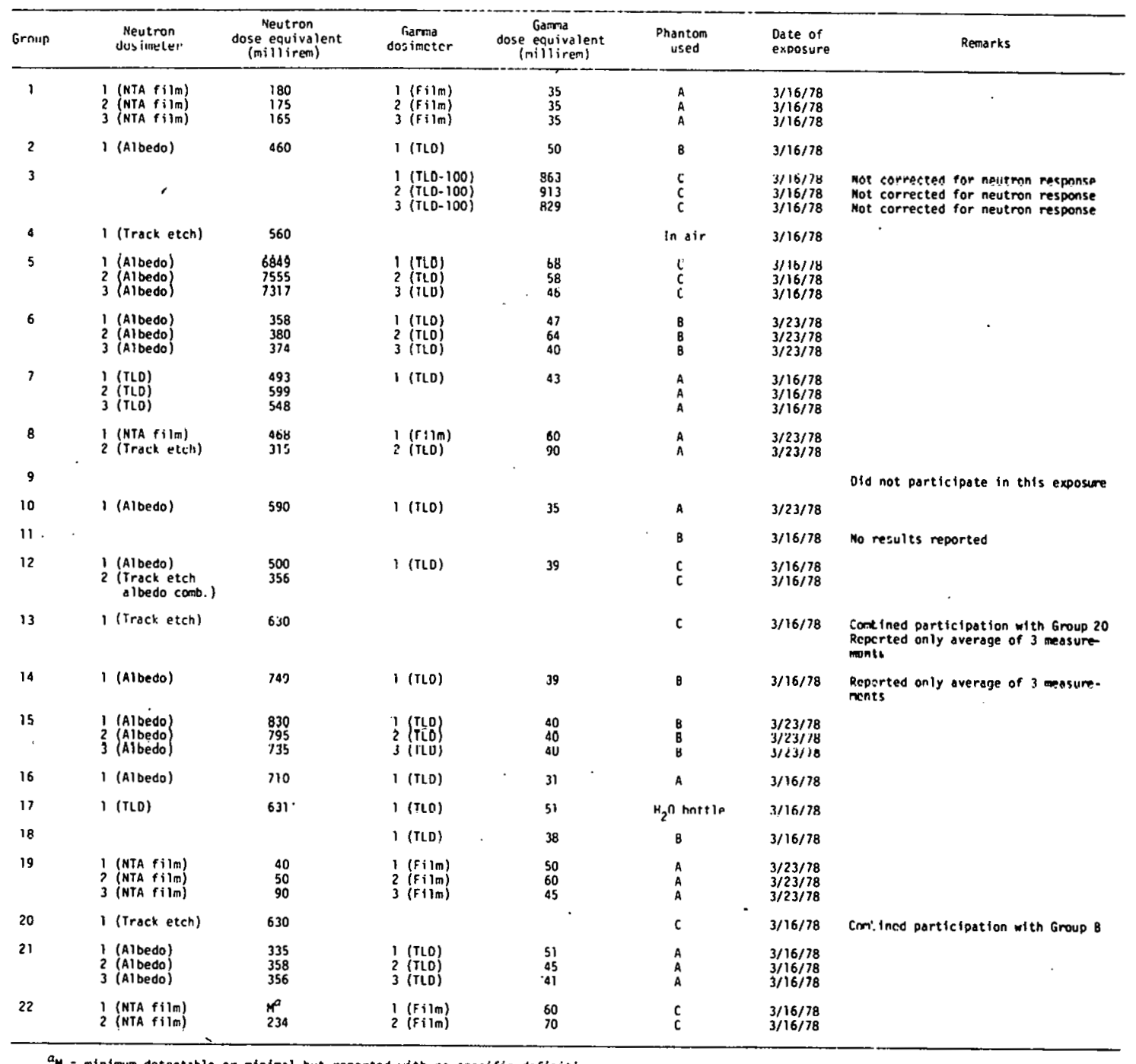


Table 10. Resuits of participant's measurements for steel/concrete-shielded HPRR exposures

\begin{tabular}{|c|c|c|c|c|c|c|c|}
\hline firoun & $\begin{array}{l}\text { Neutron } \\
\text { dosimeter }\end{array}$ & $\begin{array}{l}\text { Neutron } \\
\text { dose equivalent } \\
\text { (millirem) }\end{array}$ & $\begin{array}{l}\text { Famma } \\
\text { dosimeter }\end{array}$ & $\begin{array}{l}\text { Gamma } \\
\text { dose equivalent } \\
\text { (milli irem) }\end{array}$ & $\begin{array}{l}\text { Phantom } \\
\text { used }\end{array}$ & $\begin{array}{l}\text { Date of } \\
\text { exnosure }\end{array}$ & Remarks \\
\hline 1 & $\begin{array}{l}1 \text { (NTA film) } \\
2 \text { (NTA film) } \\
3 \text { (NTA film) }\end{array}$ & $\begin{array}{l}185 \\
170 \\
155\end{array}$ & $\begin{array}{l}1 \quad(F i l m) \\
2(F i l m) \\
3(F i l \pi)\end{array}$ & $\begin{array}{l}30 \\
35 \\
35\end{array}$ & $\begin{array}{l}\text { A } \\
\text { A } \\
\text { A }\end{array}$ & $\begin{array}{l}3 / 16 / 78 \\
3 / 16 / 78 \\
3 / 16 / 78\end{array}$ & \\
\hline 2 & 1 (A|bedo) & $9 \subseteq 0$ & $1(T L O)$ & 50 & B & $3 / 16 / 78$ & \\
\hline 3 & & & $\begin{array}{l}1 \text { (TLD-100) } \\
2(\text { ILD-100) } \\
3(\text { TLD-100) }\end{array}$ & $\begin{array}{l}915 \\
985 \\
917\end{array}$ & $\begin{array}{l}c \\
c \\
c\end{array}$ & $\begin{array}{l}3 / 16 / 78 \\
3 / 16 / 78 \\
3 / 16 / 78\end{array}$ & $\begin{array}{l}\text { Not corrected for neutron response } \\
\text { Not corrected for neutron response } \\
\text { Not corrected for neutron response }\end{array}$ \\
\hline 4 & 1 (Track etch) & 500 & & & In air & $3 / 16 / 78$ & \\
\hline 5 & $\begin{array}{l}1 \text { (Albedo) } \\
2 \text { (Albedo) } \\
3 \text { (Albedo) }\end{array}$ & $\begin{array}{l}23 \xi 7 \\
25 \notin 4 \\
1609\end{array}$ & $\begin{array}{l}1 \text { (TID) } \\
2 \text { (ILD) } \\
3 \text { (ILD) }\end{array}$ & $\begin{array}{l}128 \\
127 \\
143\end{array}$ & $\begin{array}{l}c \\
c \\
c\end{array}$ & $\begin{array}{l}3 / 16 / 78 \\
3 / 16 / 78 \\
3 / 16 / 78\end{array}$ & \\
\hline 6 & $\begin{array}{l}1 \text { (Albedo) } \\
2 \text { (Albedo) } \\
3 \text { (Albedo) }\end{array}$ & $\begin{array}{l}457 \\
423 \\
453\end{array}$ & $\begin{array}{l}1(T L D) \\
2(T L D) \\
3(T L D)\end{array}$ & $\begin{array}{l}36 \\
48 \\
43\end{array}$ & $\begin{array}{l}B \\
B \\
B\end{array}$ & $\begin{array}{l}3 / 23 / 78 \\
3 / 23 / 78 \\
3 / 23 / 78\end{array}$ & • \\
\hline 7 & $\begin{array}{l}1(T L O) \\
2(T L O)\end{array}$ & $\begin{array}{l}719 \\
838\end{array}$ & $1($ TLD) & 0 & A & $\begin{array}{l}3 / 16 / 78 \\
3 / 16 / 78\end{array}$ & \\
\hline 8 & $\begin{array}{l}1 \text { (NTA film) } \\
2 \text { (Track etch) }\end{array}$ & $\begin{array}{l}M^{a} \\
306\end{array}$ & $\begin{array}{l}1(F i l m) \\
2(T L D)\end{array}$ & $\begin{array}{r}70 \\
100\end{array}$ & A & $\begin{array}{l}3 / 23 / 78 \\
3 / 23 / 78\end{array}$ & $\cdots$ \\
\hline 9 & v & & & & & & Did not oarticipate in this exnosure \\
\hline 10 & I (Albedo) & 7,30 & $1(T L D)$ & 35 & B & $3 / 16 / 78$ & \\
\hline 11 & & & & & B & $3 / 16 / 78$ & No results reported \\
\hline 12 & $\begin{array}{l}1 .(\text { Albedo }) \\
2 \text { (Track etch } \\
\text { albedo comb.) }\end{array}$ & $\begin{array}{l}420 \\
328\end{array}$ & 1 (TLD) & 41 & c & $\begin{array}{l}3 / 16 / 78 \\
3 / 16 / 78\end{array}$ & \\
\hline 13 & (Track etch) & 620 & . & $\cdot$ & c & $3 / 16 / 78$ & $\begin{array}{l}\text { Combined participation with Group } \\
\text { Reported only average of } 3 \text { measure- } \\
\text { ments }\end{array}$ \\
\hline 14 & 1 (Albedo) & 990 & $I(T L D)$ & 38 & B & $3 / 16 / 78$ & $\begin{array}{l}\text { Reported only average of } 3 \text { measure- } \\
\text { ments }\end{array}$ \\
\hline 15 & $\begin{array}{l}1 \text { (Albedo) } \\
2 \text { (Albedo) } \\
3 \text { (Albedo) }\end{array}$ & $\begin{array}{r}930 \\
965 \\
1130\end{array}$ & $\begin{array}{l}1 \text { (TLD) } \\
2 \text { (TLD) } \\
3 \text { (TLD) }\end{array}$ & $\begin{array}{l}40 \\
40 \\
40\end{array}$ & $\begin{array}{l}\text { B } \\
\text { B } \\
\text { B }\end{array}$ & $\begin{array}{l}3 / 23 / 78 \\
3 / 23 / 78 \\
3 / 23 / 78\end{array}$ & \\
\hline 16 & 1 (Albedo) & 1000 & $1(T L D)$ & 32 & A & $3 / 16 / 78$ & \\
\hline 17 & 1 (TLD) & 741 & 1 (TLD) & 52 & $\mathrm{H}_{2} \mathrm{O}$ bottle & $3 / 16 / 78$ & \\
\hline 18 & & & $1(T L D)$ & 34 & B & $3 / 16 / 78$ & \\
\hline 19 & 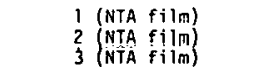 & $\begin{array}{r}0 \\
15 \\
0\end{array}$ & 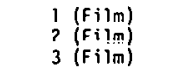 & $\begin{array}{l}50 \\
60 \\
50\end{array}$ & $\hat{A}$ & $\begin{array}{l}3 / 23 / 78 \\
3 / 83 / 78 \\
3 / 23 / 78\end{array}$ & \\
\hline 20 & I (Irack etch) & 620 & - & & c & $3 / 16 / 78$ & Combined participation with Group 13 \\
\hline 21 & $\begin{array}{l}1 \text { (Albedo) } \\
2 \text { (Albedo) } \\
3 \text { (Albedo) }\end{array}$ & $\begin{array}{l}333 \\
358 \\
372\end{array}$ & $\begin{array}{l}1(T L D) \\
2(T L D) \\
3(T L D)\end{array}$ & $\begin{array}{l}39 \\
49 \\
45\end{array}$ & $\begin{array}{l}4 \\
A \\
A\end{array}$ & $\begin{array}{l}3 / 16 / 78 \\
3 / 16 / 78 \\
3 / 16 / 78\end{array}$ & \\
\hline 22 & 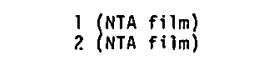 & $M_{180}^{\prime \prime}$ & 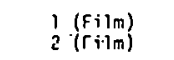 & $\begin{array}{l}70 \\
70\end{array}$ & $\begin{array}{l}c \\
c\end{array}$ & $\begin{array}{l}3 / 16 / 78 \\
3 / 16 / 78\end{array}$ & \\
\hline
\end{tabular}

$a_{M}=$ minimum detectable or minimal hut reported with no spccific definition. 
Table 11. Summary of unshielded measurements ${ }^{\alpha}$

\begin{tabular}{cccc}
\hline No. of \\
Dosimeter type \\
measurements
\end{tabular} Median Mean $\begin{gathered}\text { Standard } \\
\text { deviation( } \sigma)\end{gathered} \quad \% \sigma$

Neutrun

$\begin{array}{lrllll}\text { Albedo } & 17 & 495 & 508 & 271 & 53 \\ \text { TLD } & 3 & 595 & 578 & 63 & 11 \\ \text { NTA fi } i \mathrm{~lm} & 5 & 250 & 202 & 104 & 51 \\ \text { Track etch } & 4 & 288 & 344 & 176 & 51 \\ \text { A1 } & 29 & 457 & 440 & 252 & 57\end{array}$

Gamma $(3 / 15 / 78)$

$\begin{array}{lrrrrr}\text { TLD } & 15 & 38 & 41.2 & 18.2 & 44 \\ \text { Fi 1m } & 5 & 50 & 46.0 & 5.5 & 12 \\ \text { A11 } & 20 & 39 & 42.4 & 16.0 & 38\end{array}$.

Gamma $(3 / 23 / 78)$

$\begin{array}{lrrrrr}\text { TLD } & 10 & 15 & 18.1 & 6.3 & 35 \\ \text { Fi1m } & 3 & 35 & 31.7 & 10.4 & 33 \\ \text { A11 } & 13 & 15 & 21.2 & 9.1 & 43\end{array}$

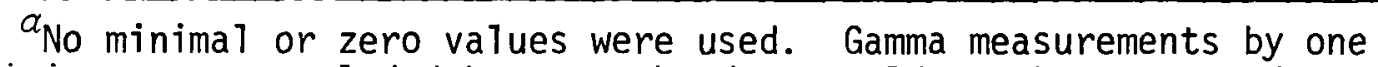
participant were excluded because the data could not be corrected fur neutron response: 
Table 12. Summary of Lucite-shielded measurements ${ }^{\alpha}$

\begin{tabular}{lccccc}
\hline Dosimeter type & $\begin{array}{c}\text { No. of } \\
\text { measurements }\end{array}$ & Median & Mean $\begin{array}{c}\text { Standard } \\
\text { deviation( } \sigma)\end{array}$ & $\% \sigma$ \\
\hline Neutron & & & & & \\
Albedo & 17 & 420 & 524 & 374 & 71 \\
TLD & 4 & 447 & 453 & 37 & 7 \\
NTA film & 5 & 205 & 169 & 89 & 53 \\
Track etch & 5 & 460 & 442 & 224 & 51 \\
A11 & 31 & 420 & 444 & 314 & 71
\end{tabular}

Gamma $(3 / 15 / 78)$

$\begin{array}{lrrrrr}\text { TLD } & 13 & 67 & 74.6 & 33.4 & 45 \\ \text { Fi 1m } & 5 & 55 & 63.0 & 15.6 & 25 \\ \text { A11 } & 18 & 64 & 71.4 & 29.6 & 41\end{array}$

Gamma (3/23/78)

\begin{tabular}{lrrrrr} 
TLD & 10 & 59 & 71.0 & 29.0 & 41 \\
Film & 5 & 80 & 78.0 & 7.6 & 10 \\
Al1 & 15 & 67 & 73.3 & 24.0 & 33 \\
Gamma & 33 & 67 & 72.3 & 26.8 & 39 \\
\hline
\end{tabular}

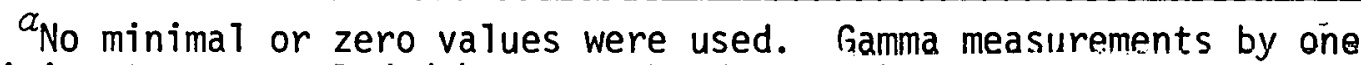
particfpant were excluded because the data could not be corrected for neutron response. 
Table 13. Summary of concrete-shielded measurements ${ }^{a}$

\begin{tabular}{|c|c|c|c|c|c|}
\hline Dosimeter type & $\begin{array}{c}\text { No. of } \\
\text { measurements }\end{array}$ & Median & Mean & $\begin{array}{c}\text { Standard } \\
\text { deviation( }(\sigma)\end{array}$ & $\% \sigma$ \\
\hline \multicolumn{6}{|l|}{ Neutron } \\
\hline $\begin{array}{l}\text { Al bedo } \\
\text { TLD } \\
\text { NTA fi } 1 \mathrm{~m} \\
\text { Track etch } \\
\text { Al1 }\end{array}$ & $\begin{array}{r}17 \\
4 \\
8 \\
4 \\
33\end{array}$ & $\begin{array}{l}\text { bUU } \\
520 \\
170 \\
458 \\
493\end{array}$ & $\begin{array}{r}1720 \\
568 \\
162 \\
465 \\
1053\end{array}$ & $\begin{array}{r}2642 \\
60 \\
205 \\
153 \\
2027\end{array}$ & $\begin{array}{r}154 \\
11 \\
127 \\
33 \\
192\end{array}$ \\
\hline \multicolumn{6}{|l|}{ Gamma $(3 / 16 / 78)$} \\
\hline $\begin{array}{l}\text { TLD } \\
\text { Fi } 1 \mathrm{~m} \\
A\rceil 1\end{array}$ & $\begin{array}{r}14 \\
5 \\
19\end{array}$ & $\begin{array}{l}44 \\
35 \\
43\end{array}$ & $\begin{array}{l}44.8 \\
47.0 \\
45.4\end{array}$ & $\begin{array}{l}10.6 \\
16.8 \\
12.0\end{array}$ & $\begin{array}{l}24 \\
36 \\
26\end{array}$ \\
\hline \multicolumn{6}{|l|}{ Gamma $(3 / 23 / 78)$} \\
\hline $\begin{array}{l}\text { TLD } \\
\text { Fi1m } \\
\text { AI } 1\end{array}$ & $\begin{array}{r}9 \\
4 \\
13\end{array}$ & $\begin{array}{l}40 \\
55 \\
45\end{array}$ & $\begin{array}{l}43.2 \\
53.8 \\
49.5\end{array}$ & $\begin{array}{r}24.2 \\
7.5 \\
15.7\end{array}$ & $\begin{array}{l}56 \\
14 \\
32\end{array}$ \\
\hline A11 Gamma & 32 & 44 & 47.1 & 13.5 & 29 \\
\hline
\end{tabular}

a no minimal or zero values were used. Gamma measurements by one participant were excluded because the data could not be corrected for neutron response. 
Table 14. Summary of steel/concrete shielded measurements ${ }^{a}$

\begin{tabular}{lllll}
\hline Dosimeter type & $\begin{array}{c}\text { No. of } \\
\text { measurements }\end{array}$ & Median & Mean $\begin{array}{c}\text { Standard } \\
\text { deviation( } \sigma)\end{array}$ & $\% \sigma$ \\
\hline
\end{tabular}

Neutron

$\begin{array}{lrrrrr}\text { Albedo } & 17 & 930 & 948 & 676 & 71 \\ \text { TLD } & 3 & 741 & 766 & 63 & 8 \\ \text { NTA film } & 5 & 170 & 141 & 71 & 50 \\ \text { Track etch } & 4 & 414 & 438 & 149 & 34 \\ \text { ATl } & 29 & 500 & 720 & 606 & 84\end{array}$

Gamma $(3 / 16 / 78)$

$\begin{array}{lrrrrr}\text { TLD } & 13 & 45 & 61.7 & 41.4 & 67 \\ \text { Fi I } & 5 & 35 & 48.0 & 20.2 & 42 \\ \text { A11 } & 18 & 43 & 57.9 & 36.6 & 63\end{array}$

Gamma (3/23/78)

$\begin{array}{lrllll}\text { TLD } & 9 & 40 & 46.1 & 20.7 & 45 \\ \text { Fi1m } & 4 & 50 & 55.0 & 10.0 & 18 \\ \text { A11 } & 13 & 43 & 48.9 & 18.1 & 37 \\ \text { Gamma } & & & & & \\ & & & & & \\ \end{array}$

${ }^{a}$ No minimal or zero values were used. Gamma measurements by one participant were excluded because the data could not be corrected for neutron response. 
Table 15. Comparison of neutron measurements of the fourth PDIS with reference dosimetry

\begin{tabular}{|c|c|c|c|c|}
\hline \multirow{2}{*}{ Shield } & \multicolumn{2}{|c|}{$\begin{array}{c}\text { Reference dosimetry } \\
\text { (millirem) }\end{array}$} & \multicolumn{2}{|c|}{$\begin{array}{c}\text { Participants results } \\
\text { (millirem) }\end{array}$} \\
\hline & $\begin{array}{l}\text { Proportional } \\
\text { counter }\end{array}$ & Sulfur & Mean $\pm \sigma$ & Median \\
\hline None & $456 \pm 50$ & $448 \div 48$ & $440 \pm 252$ & 457 \\
\hline Lucite & $441 \pm 5 U$ & $456 \pm 53$ & $444 \div 314$ & 420 \\
\hline Concrete & $434 \pm 48$ & $563 \pm 94$ & $1053 \pm 2027$ & 493 \\
\hline Stee $1 /$ Concrete & $443 \pm 50$ & $620 \pm 122$ & $720 \pm 606$ & 500 \\
\hline
\end{tabular}

Table 16. Comparison of gamma measurements of the fourth PDIS with reference dosimetry

\begin{tabular}{|c|c|c|c|c|}
\hline \multirow[b]{2}{*}{ Shield } & \multicolumn{2}{|c|}{$\begin{array}{l}\text { Reference dosimetry } \\
\text { (millirem) }\end{array}$} & \multicolumn{2}{|c|}{$\begin{array}{c}\text { Participants results } \\
\text { (millirem) }\end{array}$} \\
\hline & $\begin{array}{l}\text { Runs on } \\
3 / 15-16\end{array}$ & $\begin{array}{c}\text { Runs on } \\
3 / 23\end{array}$ & $\begin{array}{l}\text { Runis on } \\
3 / 15-16\end{array}$ & $\begin{array}{c}\text { Runs on } \\
3 / 23\end{array}$ \\
\hline None & 32 & 15 & 42.4 上 16.0 & $21.2 \pm 9.1$ \\
\hline Lucite & 41 & 53 & $71.4 \pm 29.6$ & $72.3 \pm 26.8$ \\
\hline Concrete & 27 & 33 & $45.4 \pm 12.0$ & $49.5 \pm 15.7$ \\
\hline Steel/Concrete & 24 & 33 & $57.9 \pm 36.6$ & $48.9 \pm 18.1$ \\
\hline
\end{tabular}

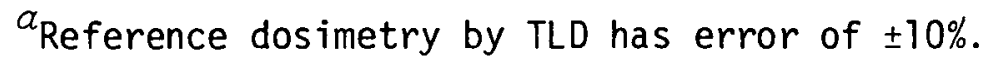




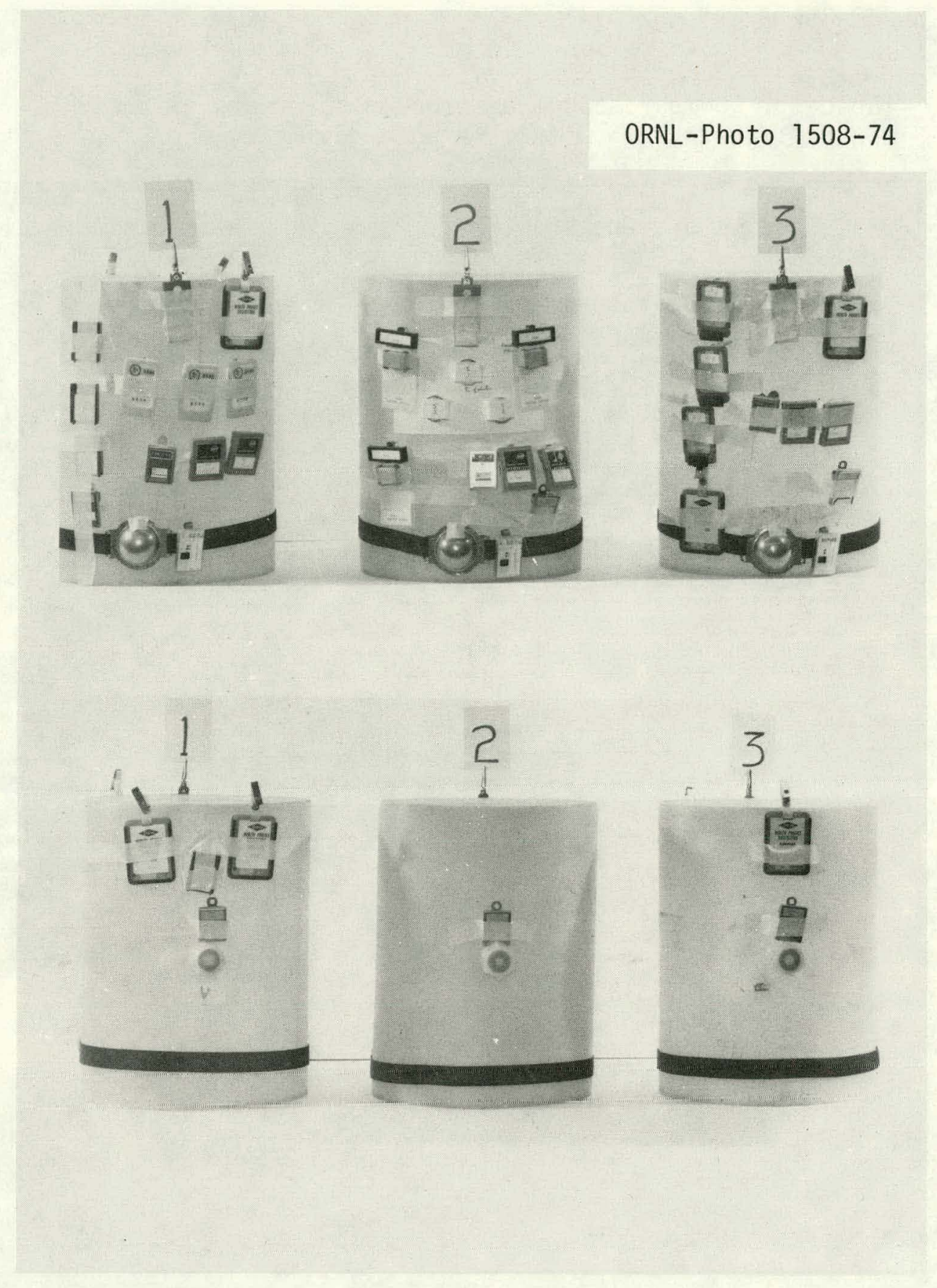

Fig. 1. Placement of dosimeters on the phantoms. Upper half of figure shows the front of the phantoms and the lower half of the figure shows the back of the phantoms. 
ORNL-Photo $1202-78 R$

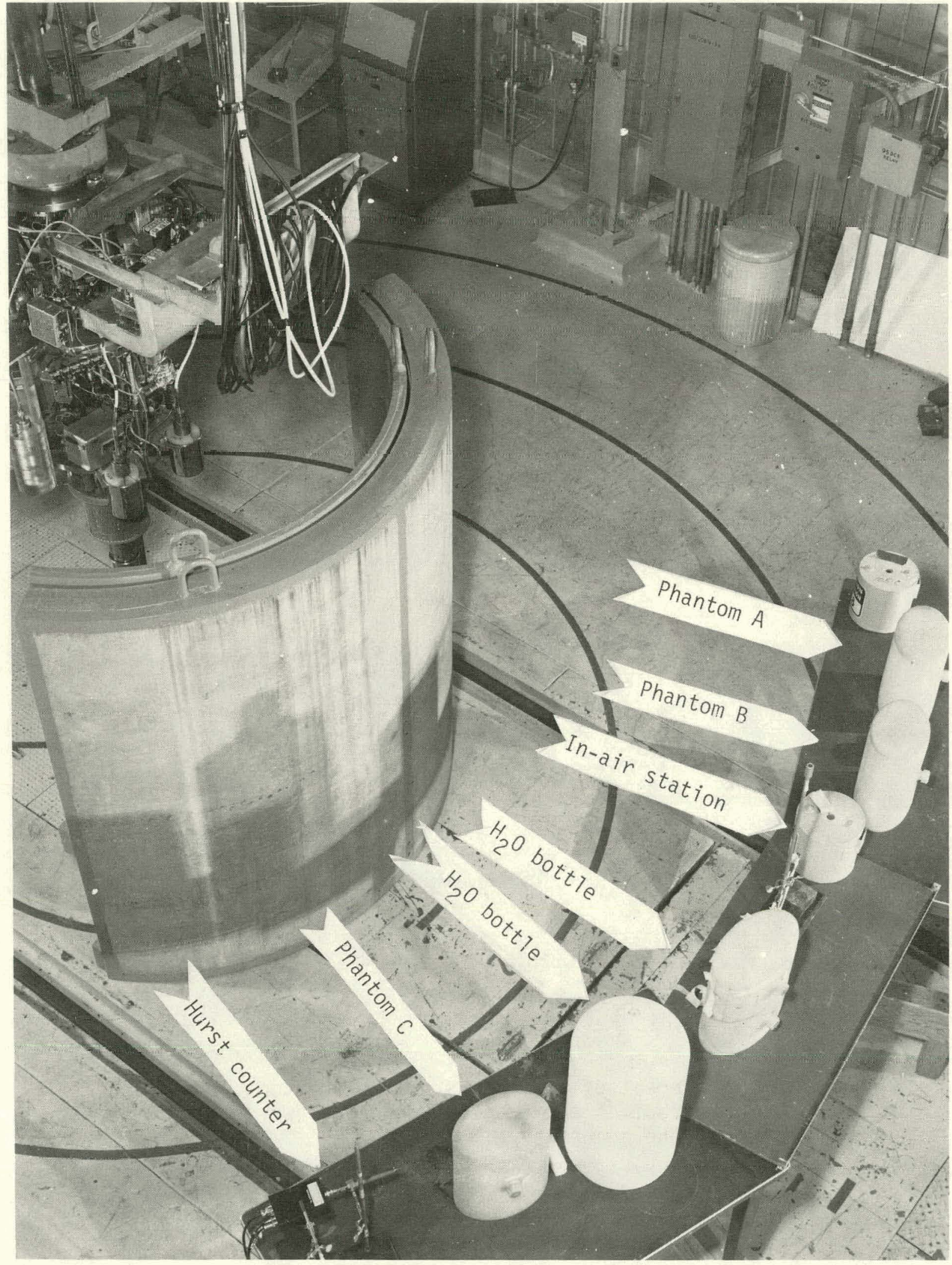

Fig. 2. Typical experimental arrangement with the steel/concrete shields in place. The Hurst proportional counter is located in the center foreground. 


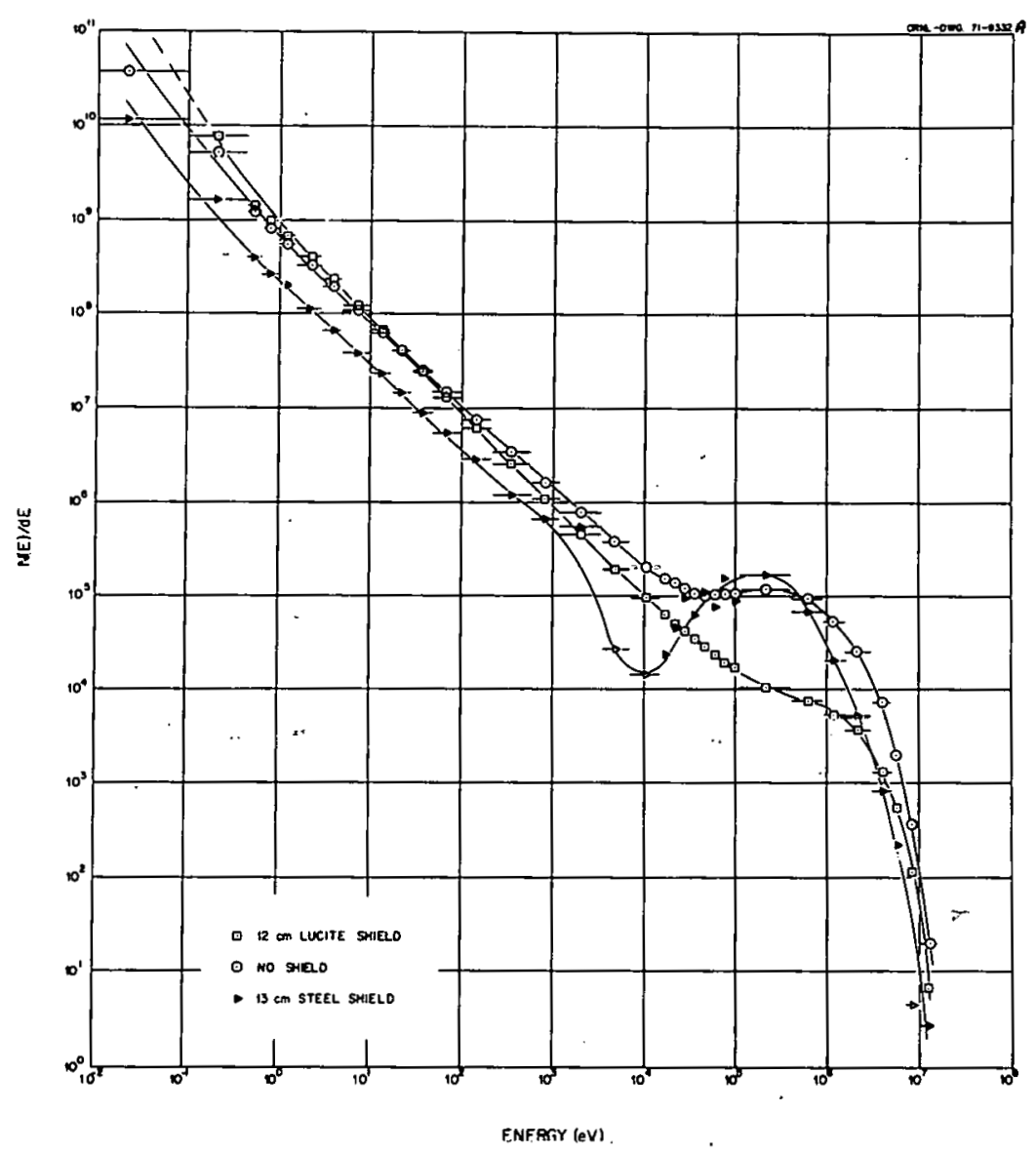

Fig. 3. Calculated HPRR leakage spectrum at 3.0 meters from the centerline of the core. 


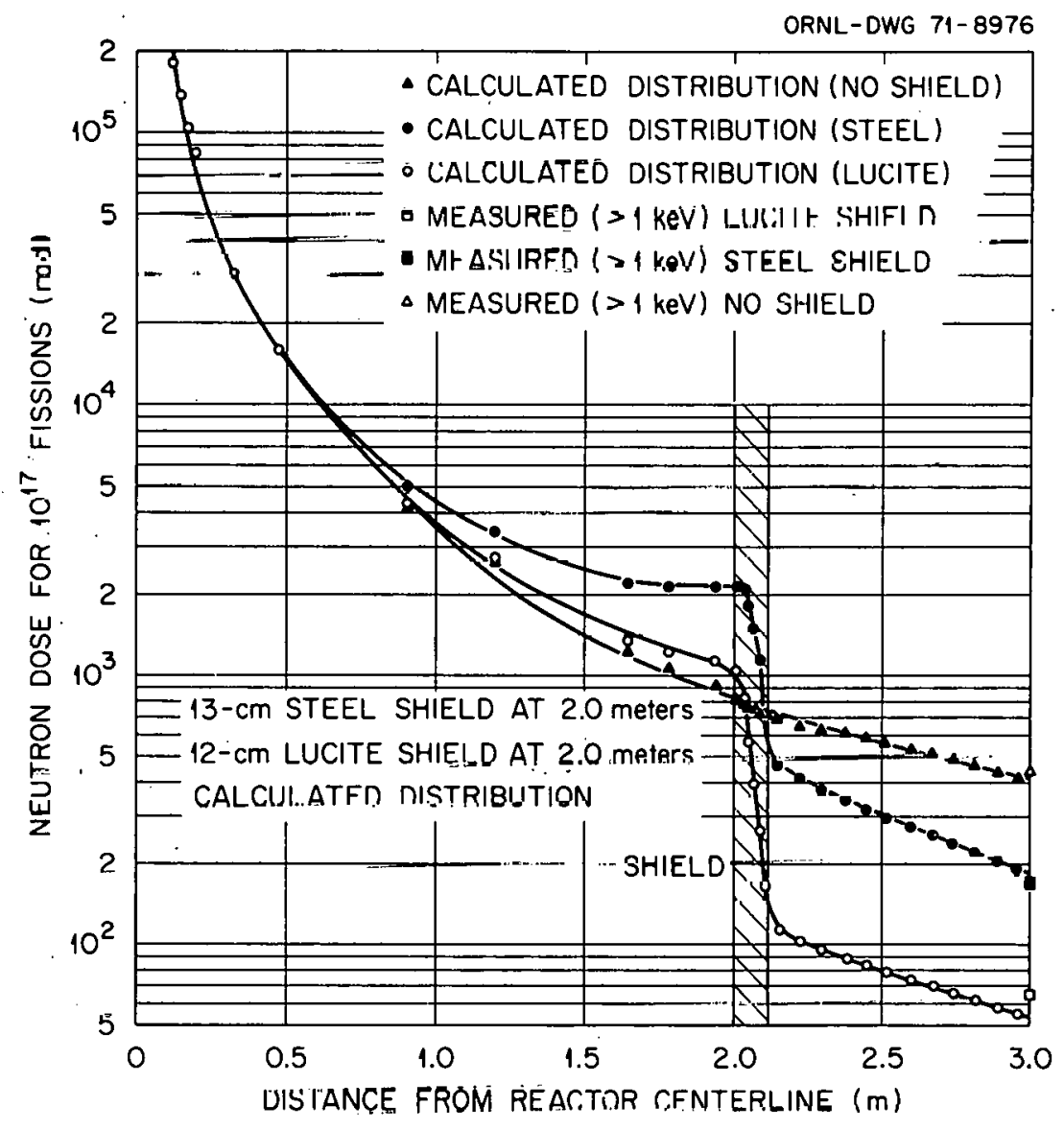

Fig. 4. Calculated neutron dose as a function of distance from the reactor centerline. 


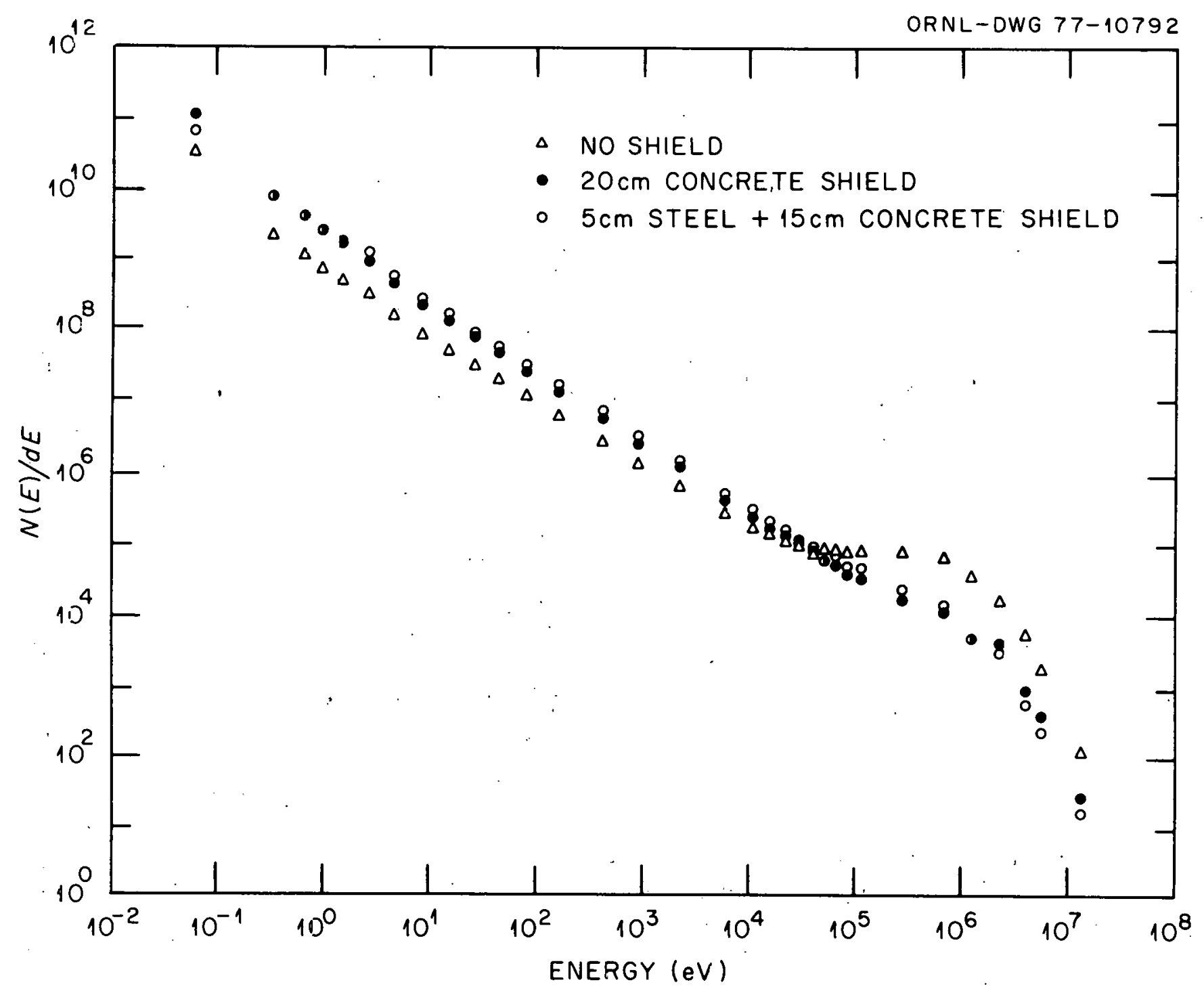

Fig. 5. Calculated HPRR leakage spectrum at $3.0 \mathrm{~m}$ from the centerline of the reactor. 


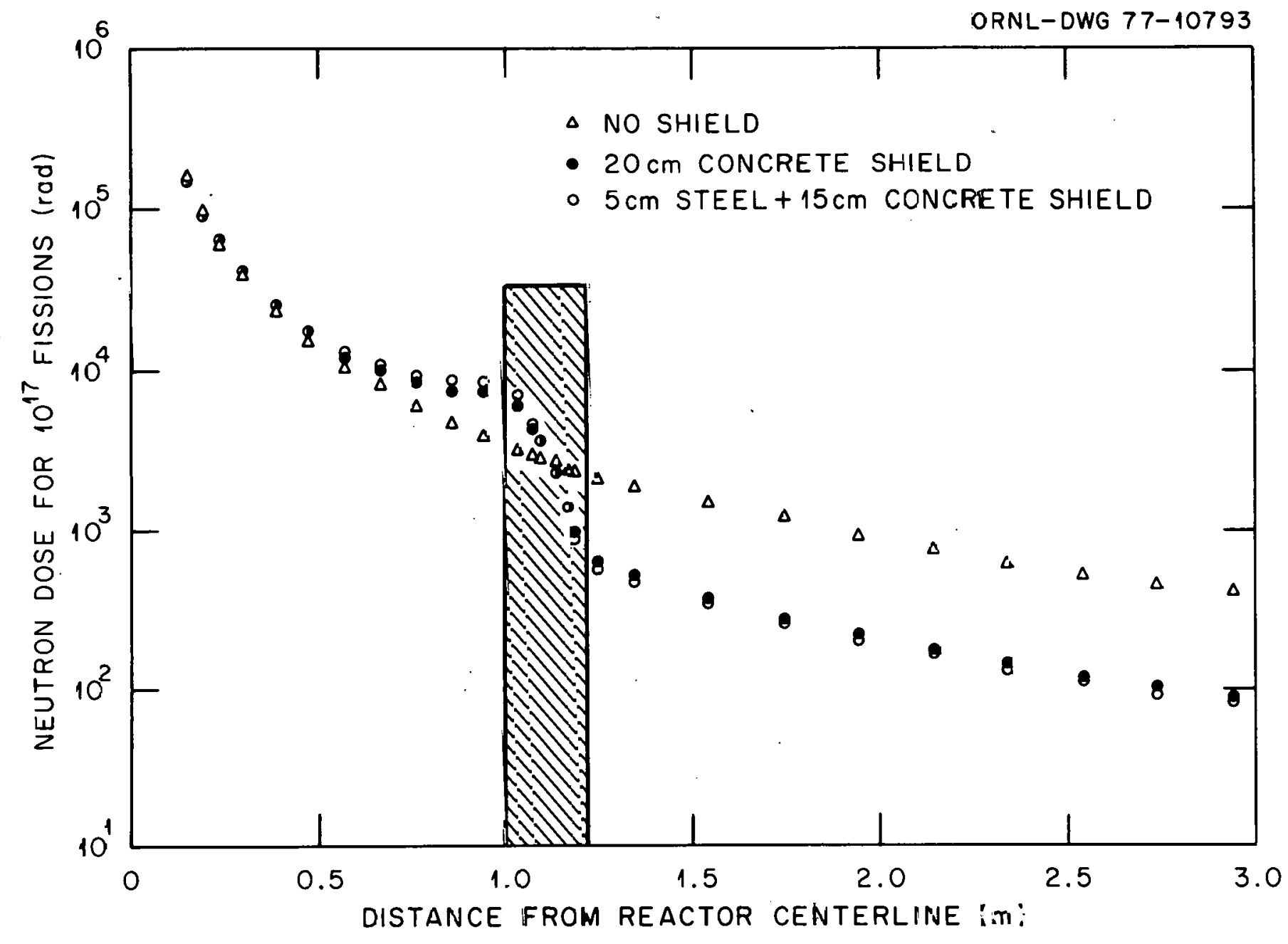

Fig. 6. Calculated nejtron dose as a function of distance from the reactor centerline. 


\section{PAGES 31 to 32 WERE INTENTIONALLY LEFT BLANK}


Participants of the fourth Personnel Dosimetry Intercomparison Study (March 15-23, 1978)

Mr. W. E. Bleiler

Argonne National Laboratory

9700 South Cass Avenue

Argonne, IL 60439

Mr. J. J. Fix

Battelle

Pacific Northwest Laboratory

P. 0. Box 999

Richland, Washington 99352

Mr. R. Gardner

Cornel1 University

925 Warren Road

Ithaca, New York 14850

Dr. Frantisek Spurny

Institute of Radiation Dosimetry

Czechoslovak Academy of Sciences

$\mathrm{Na}$ Truhlarce $39 / 22$

18086 Praha 8

Czechos lovakia

Mr. J. C. Rivera

Radiation Safety

Department of the Navy

National Naval Medical Center

Bethesda, Maryland 20014

Mr. J. P. Cusimano

Department of Energy

Idaho Operations Office

550 Sccond Street

Idaho Falls, Idaho 83401

Mr. Eric Geiger

Eberline Instrument Corporation

P. 0. Box 2108

Santa Fe, New Mexico 87501

Mr. Sam Baker

Fermi National Accelerator Laboratory

P. 0. Box 500

Batavia, Illinois 60510

Mr. Billy Short

Goodyear Atomic Corporation

P. 0 . Box 628

Piketon, Ohio

45661
Dr. Ernst Piesch

Kernforschungszentrum Karlsruhe GmbH Abteilung Strahlenschutz und Sic.er. Postfach $3640 ; 7500$ Karlsruhe. Germany

Mr. Robert Latimer, Head Environmental Health and Safety University of Cal ifornia Lawrence Berkeley Laboratory Berkeley, California

Mr. Dale E. Hankins

Hazards Control Department Lawrence Livermore Laboratory University of Cal ifornia Livermore, California 94550

Mr. Richard 0swald ${ }^{a}$

R. S. Landauer, Jr., \& Company

Glenwood Science Park

Glenwood, Illnois 60425

Dr. M. E. Remley, Manager

Health, Safety \& Radiation Services

Atomics International, A Division of Rockwe11 International Corporation Canoga Park, California 91304

Mr. C. N. Wright

E. I. du Pont de Nemours \& Company Savannah River Plant

Aiken, South Carolina 29801

Mr. Gary Warren

Stanford Linear Accelerator Center

P. 0. Box 4349

Stanford, California 94305

Mr. Carl H. Distenfeld

Consultant, Teledyne Isotopes

Teledyne Isotopes, Inc.

Westwood, New Jersey

Mr. John Lobdell

River Oaks Building

Tennessee Valley Authority

Muscle Shoals, Alabama 35660 
Mr. John Hickman

Environmental Health \& Safety

TB-30

University of California

at Davis

Davis, California 95616

Dr. Eugene V. Benton ${ }^{a}$

Department of Physics

University of San Francisco

San Francisco, California 94117

Dr. W. R. Harris, Manager

Health Physics and Environmental Engineering

Westinghouse Electric Corporation

F. 0. Dok 7y

Bettis Atomic Power Laboratory

West Mifflin, Pennsylvania 15122

Mr. John E. Flynn

Yale University

University Health Sciences

Health Physics Division

New Haven, Conneticut 06520

a Joint participation, one set of data. 
ORNL/TM-7137

INTERNAL DISTRIBUTION
1-2. Central Research Library
3. Document Reference Section
4-5. Laboratory Records Department
6. Laboratory Records, ORNL, R.C.
7. ORNL Patent Office
8. H. W. Dickson
9. C. E. Easterly
10. L. W. Gilley
11. F. F. Haywood

12. S. V. Kaye

13. J. R. Muir

14. D. C. Parzyck

15. P. S. Rohwer

16. B. F. Rutherford $(Y-12)$

17. C. S. Sims

18. C. M. West $(Y-12)$

19-39. DOSAR ( files)

EXTERNAL DISTRIBUTION

40. Office of Assistant Manager, Energy Research and Development, Department of Energy, Oak Ridge Operations, Oak Ridge, TN 37830

41. Sam Baker, Fermi National Accelerator Laboratory, P.0. Box 500, Batavia, IL 60510

42. Louis Battist, Office of Standards Development, U.S. Nuclear Regulatory Commission, Washington, DC 20555

43. Eugene V. Benton, Department of Physics, University of San Francisco, San Francisco, CA 94117

44. W. E. Bleiler, Argonne National Laboratory, 9700 South Cass Avenue, Argonne, IL 60439

45. James T. Brennan, University Hospital, University of Pennsylvania, 3400 Spruce Street, Philadelphia, PA 19104

46. G. Cowper, Health Physics Branch, Atomic Energy of Canada, Ltd., Chalk River Nuclear Laboratories, Chalk River, Ontario, Canada

47. T. R. Crites, Lawrence Livermore Laboratory, P. 0. Box 808, Livermore, CA 94550

48. William T. Crow, Office of Nuclear Material Safety and Safeguards, U.S. Nuclear Regulatory Commission, 7915 Eastern Avenue, Silver Spring, MD 20555

49. J. P. Cusimano, Department of Energy, Idaho Operations Office, 550 Second Street, Idaho Fal15, ID 83401

50. L. J. Deal, Division of Operational and Environmental Compliance, Department of Energy, Washington, DC 20545

51. Carl H. Distenfeld, Teledyne Isotopes, Inc., Westwood, NJ

52. W. P. Ellis, Standards and Procedures Branch, Division of Compliance, U.S. Nuclear Regulatory Commission, Washington, DC 20555

53. R. B. Falk, Rockwell Internation, Rockly Flats Plant, P.0. Box 464, Golden, CO 80401

54. J. J. Fix, Battelle Pacific Northwest Laboratory, P.0. Box 999, Richland, WA 99352 
55. J. E. Flynn, Yale University, University Health Sciences, Health Physics Division, New Haven, CT 06520

56. R. Gardner, Cornell University, 925 Warren Road, Ithaca, NY 14850

57. Eric Geiger, Eberline Instrument Corporation, P.0. Box 2108, Santa Fe, NM 87501

58. R. V. Griffith, Lawrence Livermore Laboratory, P.0. Box 808, Livermore, CA 94550

59. Dale E. Hankins, Hazards Control Department, Lawrence Livermore Laboratory, University of California, Livermore, CA 94550

60. W. R. Harris, Health Physics and Environmental Engineering, Westinghouse Electric Corporation, P.0. Box 79, Bettis Atomic Power Laboratory, West Mifflin, PA 15122

61. John Hickman, Environmental Health and Safety, TB-30, University of California at Davis, Davis, CA 95616

62. 1. E. Hoy, Radiological Sciences Division, Savannah River Laboratory, Aiken, SC 29802

63. Harry Ing, Atomic Energy of Canada, Ltd., Chalk River Nuclear Laboratory, Chalk River, Ontario, Canada

64. Robert Latimer, Environmental Health and Safety, University of California, Lawrence Berkeley Laboratory, Berkeley, CA

65. John Lobde11, River Oaks Building, Tennessee Valley Authority, Muscle Shoals, AL 35660

66. S. A. McGuire, Office of Standards Development, U.S. Nuclear Regulatory Commission, Washington, DC 20555

67. Leigh Phillips, Health Physics and Safety Division, Brookhaven National Laboratory, Upton, NY 11973

68. Ernst Piesch, Kernforschungszentrum Karlsruhe GmbH, Abteilung Strahienschutz und Sic.er.eit, Postfach 3640, 7500 Karlsruhe, Germany

69. M. E. Remley, Health, Safety and Radiation Services, Atomics Internationa 1, Canoga Park, CA 91304

70. J. C. Rivera, Radiation Safety, Department of the Navy, National Naval Medical Center, Bethesda, MD 20014

71. C. F. Sanders, Westinghouse Nuclear Fuel Division, P.O. Drawer R, Columbia, SC 29205

72. Billy Short, Goodyear Atomic Corporation, P.0. Box 628, Piketon, $\mathrm{OH} \quad 45661$

73. Frantisek Spurny, Institute of Radiation Dosimetry, Czechusluvak Academy of Sciences, Na Truhlarce 39/22, 18086 Praha 8, Czechos10vakia

74. Gary Warren, Stanford Linear Accelerator Center, P.0. Box 4349, Stanford, CA 94305

75. R. V. Wheeler, R. S, Landauer, Jr., and Company, Glenwoud Science Park, Gienwood, IL 60425

76. R. W. Wood, Division of Pollutant Characterization and Safety Research, Department of Energy, Washington, DC 20545

77. C. N. Wright, E. I. du Pont de Nemours and Company, Savannah River Plant, Aiken, SC 29801

78-104. Technical Information Center, Department of Energy, Oak Ridge, TN 37830 